\title{
Role of Visceral Adipose Tissue in Aging
}

\author{
Derek M. Huffman ${ }^{1,3}$ and Nir Barzilai ${ }^{1,2,3}$ \\ ${ }^{1}$ Department of Medicine, Albert Einstein College of Medicine, Bronx, New York \\ 2 Department of Genetics, Albert Einstein College of Medicine, Bronx, New York \\ ${ }^{3}$ Institute for Aging Research, Albert Einstein College of Medicine, Bronx, New York
}

\begin{abstract}
Visceral fat (VF) accretion is a hallmark of aging in humans. Epidemiologic studies have implicated abdominal obesity as a major risk factor for insulin resistance, type 2 diabetes, cardiovascular disease, stroke, metabolic syndrome and death. Utilizing novel rodent models of visceral obesity, studies have demonstrated a causal relationship between VF and age-related diseases. In contrast, surgically removing large quantities of subcutaneous (SC) abdominal fat does not consistently improve metabolic parameters in humans or rodents, suggesting that SC fat accrual is not an important contributor to metabolic decline. There is also compelling evidence in humans that abdominal obesity is a stronger risk factor for mortality risk than general obesity. Likewise, we have shown that surgical removal of VF improves mean and maximum lifespan in rats, providing the first causal evidence that VF depletion may be an important underlying cause of improved lifespan with CR. Given the hazards of VF accumulation on health, treatment strategies aimed at selectively depleting VF should be considered as a viable tool to effectively reduce disease risk in humans. In summary, this review provides both corollary and causal evidence for the importance of accounting for body fat distribution, and specifically VF, when assessing disease and mortality risk.
\end{abstract}

\section{Obesity and disease}

The prevalence of overweight (body mass index $>25$ ) and obesity (body mass index $>30$ ) now effects nearly two thirds of Americans and has reached epidemic proportions in most of the developed world. Obesity increases the risk for several co-morbidities including type 2 diabetes (T2DM) [1], stroke [2], cardiovascular disease (CVD) [3], and metabolic syndrome [4]. In a report from the National Health and Nutrition Examination Survey III (NHANES III), by comparison with normal weight men, the odds of having metabolic syndrome increase in a dose-response manner from overweight (5.2), moderately obese (25.2), to severely obese (67.7) [5]. More recently, the risks associated with obesity have been extended to cancer [6,7] including, prostate [8], breast [9], liver [10], kidney [10], colon [11], ovarian [12], and endometrial cancers [13].

\section{Abdominal obesity and disease risk in humans}

The fundamental cause of obesity is a long-term imbalance in energy intake and expenditure (i.e., positive energy balance) leading to the increased body mass including the accumulation of subcutaneous (SC) and visceral fat (VF). Although general obesity is an important risk factor for many diseases, several human studies have demonstrated that VF accrual, which is the fat located in the viscera, as most strongly related to many health conditions, including CVD,

Please address all correspondence to: Nir Barzilai, M.D., Institute for Aging Research, Departments of Medicine and Molecular Biology, Belfer Building, Suite 701, The Albert Einstein College of Medicine, 1300 Morris Park Avenue, Bronx, NY 10461, Tel: (718) 430-3312, Fax: (718) 430-8557, barzilai@ aecom.yu.edu. 
insulin resistance and T2DM [14]. The mechanism(s) linking VF with the metabolic syndrome is not entirely clear, but it has been suggested to involve its anatomical location, leading to a 'portal' effect of greater free fatty acids (FFA) and glycerol release [15]. More recently, evidence has shown that adipose tissue is an active endocrine organ, capable of secreting many cytokines, often referred to as adipokines, that can promote inflammation and interfere with insulin action [16]. Furthermore, studies from our group and others have shown that SC and VF are biologically distinct, with VF demonstrating far greater pro-inflammatory characteristics than SC fat. In the remainder of this review, we will discuss 1) the epidemiologic and surgical data in humans linking VF and not SC fat to disease, 2) animal studies which demonstrate a causal relationship between $\mathrm{VF}$, but not $\mathrm{SC}$ fat accumulation to metabolic decline with aging, 3) statistical and experimental data in humans and rodents linking VF accretion to mortality risk and lifespan, and 4) treatment strategies aimed at reducing disease risk by depleting VF stores.

\subsection{Human Epidemiologic studies}

The ability to prevent or delay the onset of disease is a critical determinant of lifespan. Some diseases are not treatable or preventable and have an inheritable component of risk. However, the leading causes of death and co-morbidites in humans, including CVD, stroke and T2DM are age-related conditions that can be largely prevented or delayed by lifestyle interventions [17]. Epidemiologic studies have revealed that a common yet preventable risk factor for these diseases is the accumulation of VF, which is a hallmark of aging in humans [18]. Using either waist circumference and/or waist-to-hip ratio as a proxy of abdominal obesity, numerous studies have found that VF is a stronger risk factor for insulin resistance, T2DM [19], CVD [20], stroke [21] and heart failure [22] than body mass index (BMI) or other fat depots. However, the hazards of abdominal obesity are not only limited to metabolic disorders, but also to cognitive decline, [23], Alzheimer's disease [24] and disability [25].

\subsection{Liposuction of $\mathrm{SC}$ fat in humans}

Several studies have reported on the metabolic consequences of surgically removing large quantities of SC fat by liposuction. The general premise of these studies is that absolute fat mass is the most important contributor to obesity-related complications such that large-scale removal of abdominal SC fat should improve several metabolic parameters including insulin sensitivity. Results from these studies have been contradictory with some showing beneficial effects of liposuction on insulin sensitivity [26-29] but not others [30,31] while one reported an improvement in the blood lipid profile, but not in insulin sensitivity [32]. It has been suggested that the conflicting nature of these studies is due to several uncontrolled confounders including the way that insulin sensitivity was assessed, failure to match properly for baseline parameters, poor control of behavioral confounders after the procedure and the removal of varying amounts of SC fat [33].

A study by Klein et al. [33] attempted to definitively address the potential of liposuction as a tool to treat obesity-related metabolic disorders by controlling for the aforementioned confounders. In a study consisting of 15 obese patients (8 non-diabetic controls and 7 T2DM patients) with similar BMI, several metabolic parameters were assessed before and 10-12 weeks after having $\sim 10.5 \mathrm{~kg}$ of SC abdominal fat removed. Utilizing the euglycemichyperinsulinemic clamp procedure, they found that liposuction did not significantly alter insulin action in muscle, liver, or adipose tissue, or plasma levels of C-reactive protein (CRP), interleukin-6 (IL-6), tumor necrosis factor- $\alpha$ (TNF- $\alpha$ ), adiponectin, glucose, insulin, blood lipids and blood pressure. Therefore, surgically removing large quantities of SC abdominal fat does not appear to be sufficient to improve metabolic parameters, and suggests that SC fat is not an important component of obesity-related metabolic disorders in humans. 


\section{Animal models of obesity and disease}

Human studies have clearly demonstrated that obesity, and specifically VF accrual is strongly associated with disease risk [14]. In order to better understand the pathophysiology of obesity in mammalians, several strategies have been developed and implemented including, high-fat feeding in rodents [34] and dogs [35], seasonal models of obesity [36], transgenic mice [37] and spontaneous mutants such as $o b / o b$ and $d b / d b$ mice [38]. A common feature of obese animal models is a marked increase in VF and hyperinsulinemia, but similar to human studies, the distinct contribution of body fat distribution in these models cannot be directly elucidated. However, clever experimental strategies in animal models have been utilized which have overcome this inherent limitation and demonstrated a causal role for VF, rather than SC fat, in the etiology of insulin resistance, atherosclerosis and aging in mammalians.

\subsection{Transgenic Model of Visceral Obesity}

Excess glucocorticoids are known to promote VF deposition and insulin resistance in obesity [39]. Since glucocorticoids can be produced locally by the enzyme $11 \beta$ hydroxysteroid dehydrogenase type 1 (11 $\beta$ HSD-1), Masuzaki et al. [40] produced transgenic mice overexpressing this enzyme in adipose tissue. These mice were reported to be hyperphagic, despite elevated leptin levels, obese and displayed greater levels of corticosterone in fat. Most important, transgenic mice displayed exaggerated visceral obesity on a high-fat diet as compared to controls. Furthermore, transgenic animals demonstrated greater adipokine levels than controls, hyperlipidemia, glucose intolerance and hyperinsulinemia.

\subsection{Fat transplantation models}

Using a surgical approach, Ohman et al. [41] determined whether transplanting epididymal fat pads from C57BL/6J mice could affect vascular disease in atherosclerosis-prone apolipoprotein E-deficient (ApoE-/-) mice. Plasma from ApoE-/- mice receiving fat transplants displayed elevated levels of leptin, resistin, and monocyte chemoattractant protein-1 (MCP-1) compared with plasma from sham-operated mice. Furthermore, mice transplanted with VF developed significantly more atherosclerosis than controls. In contrast, SC fat transplants did not accelerate atherosclerosis despite a similar degree of inflammation, suggesting that VF rather than $\mathrm{SC}$ fat-related inflammation accelerates atherosclerosis development in this model.

\subsection{Surgical removal of visceral fat}

Using a different surgical approach to demonstrate causality between VF and disease, we and others have selectively removed perinephric and epididymal fat pads from rats and mice and studied its impact on insulin action. Please refer to Table 1 for a summary of the metabolic effects of VF removal in rodents. In an initial study [42] from our lab, young moderately-obese Sprague-Dawley (SD) rats were randomized either to surgical removal of VF (VF-) or to sham operation $(\mathrm{VF}+)$. Since the VF that was removed accounted for only $\sim 10 \%$ of total fat mass (FM), there was no difference between groups for body weight or total FM. Nevertheless, VFrats demonstrated significantly reduced insulin levels, and during a glucose clamp, the rates of insulin infusion required to maintain plasma glucose levels and hepatic glucose production were reduced by $50 \%$. More recently, we have shown that VF accretion is an important determinant of hepatic insulin resistance during pregnancy, which can be largely prevented by surgical removal of VF prior to mating [43], providing further evidence that VF directly impacts hepatic insulin action.

Borst et al. [44] studied the impact of VF removal on insulin action and skeletal muscle glucose transport in male SD rats. VF removal in rats tended to improve glucose tolerance (15\% reduction in glucose AUC) and significantly lowered some pro-inflammatory adipokines in 
serum. Most striking, VF- animals displayed increased insulin-stimulated glucose transport in excised soleus and digitorum longus muscle as compared to sham-operated controls. Overall, these studies provide verification that VF is a potent modulator of both hepatic and peripheral insulin action.

Our group [45] and others [46] have also demonstrated a protection from T2DM in rodents with VF removal. In our study, 2 month-old Zucker Diabetic Fatty (ZDF) rats were assigned to receive either a sham operation (ZDVF+), or surgical removal of VF (ZDVF-) [45]. Despite no differences in plasma glucose or FFA levels, ZDVF- rats had a marked reduction in fasting insulin levels by $\sim 50 \%$. In addition, during a glucose clamp, ZDVF- rats demonstrated a greater glucose infusion rate and insulin suppression of glucose production than controls. Furthermore, when rats were monitored longitudinally, the development of diabetes, as determined by fasting glucose, was delayed in ZDVF-rats but not in sham-operated rats.

Using a mouse model of diet-induced obesity and T2DM, Pitombo et al. [46] assessed the impact of VF removal on glucose metabolism, insulin signaling and serum adipokine levels. Control mice became diabetic and hyperinsulinemic, but VF removal partially restored metabolic parameters. In addition, VF removal completely attenuated the impairment of insulin signaling observed in muscle from control animals and lowered serum adipokines to near normal levels. Taken together, these studies demonstrate the ability of VF removal to prevent T2DM in both a spontaneous and diet-induced obesity-prone rodent model.

\subsection{Expansion of $S C$ adipose tissue improves metabolic parameters}

Kim et al. [47] hypothesized that a major link between obesity and insulin resistance is due to a limited ability to expand SC adipose tissue leading to the expansion of other fat depots and ectopic fat deposition in skeletal muscle and liver. In order to test this hypothesis, they overexpressed adiponectin in $o b / o b$ mice. They observed that mice lacking leptin while overexpressing adiponectin showed a dramatic improvement in the metabolic profile including normalized glucose and insulin levels and lower triglyceride levels. They also displayed reduced macrophage infiltration in adipose tissue and systemic inflammation. Most striking, the transgenic mice were morbidly obese, weighing nearly $100 \mathrm{~g}$ by $20 \mathrm{wks}$ of age as compared to ob/ob littermates that weighed nearly $40 \mathrm{~g}$ less. Furthermore, transgenic mice had much greater fat mass including SC fat mass, but less relative VF (VF\% of total body wt) than ob/ ob mice and less triglycerides in muscle and liver. In summary, these data illustrate an interesting paradox which is in line with other studies showing no metabolic benefit to SC fat removal. Specifically, massive expansion of the $\mathrm{SC}$ fat depot is not harmful but instead appears to be beneficial for insulin action by preventing ectopic and VF deposition.

\section{Abdominal Obesity and Mortality Risk in Humans}

Several studies have reported that obesity, generally defined as a BMI $>30$, increases the risk of disease specific and all-cause mortality [48-51] and reduces life expectancy [52]. Fontaine et al. [52] reported that Caucasian men and women who reached a BMI $>40$ between the ages of 20-29 years, could expect a reduction in remaining years of life expected by approximately 6 and 12 years, respectively. Obesity has not only been linked to a reduced life expectancy but also to accelerated aging as demonstrated by obese women having telomeres that were $240 \mathrm{bp}$ shorter lean women of a similar age [53].

Since abdominal obesity, as assessed by waist circumference or the waist-to-hip ratio in large population studies, has emerged as a stronger predictor of disease risk than BMI, studies have begun assessing the mortality risk posed by abdominal obesity [54-56]. Wannamethe $e$ al. [57] found that a particularly high waist circumference $(>102 \mathrm{~cm}$ ), waist-to-hip ratio (top quartile), and a composite of waist circumference and sarcopenia were the strongest predictor 
of mortality in men. More recently, a large cohort study in Europe reported that general (BMI) and abdominal adiposity (waist circumference; waist-to-hip ratio) are both strong predictors of mortality risk but that the importance of abdominal obesity was most striking among persons with a low BMI [58].

\section{The controversy of body fat in caloric restriction-associated longevity}

Studies dating back to the early 1900's by Moreschi and Rous, and later by McCay and Tannenbaum $[59,60]$, respectively, were the first to demonstrate that a reduction in food intake was capable of increasing lifespan and inhibiting tumor formation in rats [61]. Nearly a century later, calorie restriction (CR) remains the only known behavioral intervention capable of delaying the onset of many age-related diseases and extending maximal longevity $[62,63]$. This finding has since been extended to several diverse organisms including yeast, nematode, water flea, fruitfly, dog, and cow [60,62,64-66].

The fact that limiting calorie intake has such profound effects on mammalian aging and disease is intriguing, because it suggests that the rate of biological aging is intimately related to energy metabolism. In the laboratory, CR is generally implemented by limiting food intake $20-40 \%$ of ad libitum-fed controls [67]. Thus, the beneficial effects of CR have historically been attributed to a reduction in food intake [68-70]. However, this simplistic view has recently been called into question since CR is not only characterized by less food intake, but also by concurrent changes energy balance, body mass, and body composition [71,72]. Since adipose tissue has been historically viewed as an inert storage depot for triglycerides, this robust phenotypic change had been widely discounted as merely a byproduct of reducing food intake $[68,69,73]$. It was not until 1960 that a reduction in fat stores was proposed as an important mediator of CR [74]. Since many believed CR worked by slowing metabolism or retarding growth and development, this hypothesis was never fully embraced at the time, although it was neither discounted until 20 years later.

\subsection{Evidence against a role for body fat in determining lifespan}

In 1980 and 1984, respectively, two historic studies were published which essentially discredited the "Reduction of Body Fat Hypothesis" for many years. The first by Bertrand and colleagues [68] reported that fat mass was not related to lifespan in ad libitum-fed rats, but was paradoxically associated with a greater lifespan in calorie-restricted rats. The later study by Harrison et al. [73] found that calorie-restricted $o b / o b$ mice were longer lived than $a d$ libitum-fed wild types, despite having nearly twice as much body fat. Indeed, these studies made a compelling case against a role for body fat in the determination of lifespan. However, the conclusions of these studies have since been criticized and debated $[69,72]$. There has also been controversy regarding the role of body fat in both spontaneous and transgenic long-lived mutants. For instance, several models of growth hormone $(\mathrm{GH})$ deficiency or resistance including the Ames dwarf, Snell dwarf, and the GHR - - mouse have reduced body size and live substantially longer than controls. However, these mice all have a high percentage body fat, although to the best of our knowledge, body fat distribution in these models has not been reported.

\subsection{A paradigm shift}

Since the discovery of leptin in 1994 [75], the view of adipose tissue as an inert storage depot began to change. Indeed, evidence began to mount that obesity and specifically VF is associated with a low-grade inflammation due to the increased secretion of numerous pro-inflammatory cytokines from adipocytes and their associated macrophages [76,77]. Many of these cytokines also referred to as "adipokines" including leptin, TNF- $\alpha$, IL-6, heparin-binding epidermal growth factor (HB-EGF), and vascular endothelial growth factor (VEGF) among others, may 
play an important role in many disease pathologies by promoting angiogenesis, inflammation, cell proliferation, and insulin resistance [77,78]. Considering this new perspective of fat, coupled with studies from our group linking age-related changes in body composition with insulin resistance, we hypothesized that the ability of CR to improve insulin action is by reducing VF.

\subsection{VF removal in rats mimics the benefits of $C R$ on insulin action}

Since CR limits the accumulation of VF and preserves hepatic insulin action with aging in mammals [79] and extends lifespan in a variety of species [80], we suspected that the ability of $\mathrm{CR}$ to prevent insulin resistance with aging was due to the attenuation of VF, rather than other fat depots. To directly test this hypothesis, we studied four groups of rats: VF-, SC(equivalent $\mathrm{SC}$ fat removed), SO (sham-operated controls), and CR (CR+sham operated) [45]. Post-absorptive plasma insulin levels were nearly 50\% greater in the SC- and SO rats as compared to CR and VF- animals. During a glucose clamp, VF- rats had an $80 \%$ increase in the rate of glucose infusion, significantly greater glucose uptake, and 50\% increase in the ability of insulin to suppress hepatic glucose production compared to SC- and SO rats. Most striking, the dramatic improvement in insulin action with VF, but not SC fat removal, closely resembled the effects of prolonged CR, suggesting that decreased VF could largely account for the beneficial effects of a reduction in food intake. Additionally, our earlier studies had a shown a causal role for VF in age-related metabolic decline [72] leading us to revisit the body fat and longevity hypothesis by proposing that the ability of CR to improve longevity is by reducing VF.

\subsection{VF removal in rats improves longevity}

As previously mentioned, $\mathrm{VF}$ accretion is a common hallmark of aging, and we have demonstrated metabolic benefits to VF removal [79], and that decreased VF largely accounts for the improvement in insulin action with CR [45,79]. Therefore, it seemed plausible that the beneficial effects of CR on longevity may be due to the attenuation of VF [72]. Quite surprisingly, very few rodent studies have found a role for body fat in the determination of lifespan. In the most widely cited report by Bluher et al. in 2003, fat-specific insulin receptor knockout (FIRKO) mice showed a modest reduction in body mass, but were markedly leaner than controls, demonstrating a 50\% reduction in fat mass and lived nearly $20 \%$ longer than controls. Using a mathematical approach, Wang et al. [81] found that CR and body weight had independent effects on mortality rate in male Wistar rats, such that statistically, body weight accounted for approximately $11 \%$ of the CR effect on mortality rate. However, this study may have underestimated the importance of body fat and specifically VF, since body composition was not measured.

In order to definitively demonstrate that VF modulates longevity, we prospectively studied lifespan in 3 groups of rats: ad libitum fed (AL), 40\% CR and VF- rats [82]. CR rats demonstrated the greatest survival among all experimental groups (Fig. 1). Statistical analysis revealed a significant increase in both mean and maximum lifespan for VF- rats as compared to AL fed animals and VF removal accounted for $\sim 20 \%$ of the effect of CR on longevity. Furthermore, the hazard rate of death in the VF- group was 0.49 ( $51 \%$ reduction) and in the CR group was 0.13 (87\% reduction) compared to the AL-fed group. This effect of VF per se was even more remarkable when considering that VF- rats had similar food intake, body weight and body fat as AL controls. In fact, VF- animals were $220 \mathrm{~g}$ heavier, had nearly $115 \mathrm{~g}$ more body fat and a percentage body fat nearly double that of CR rats. Furthermore, the only fat pads removed were the epididymal and perinephric fat pads, which do not drain into the portal vein in rats. This raises the possibility in humans that VF depletion may be even more beneficial since VF depots in humans have direct portal access and hence a greater potential to harm the liver. An illustration of the proposed link among VF, age-related diseases and lifespan can be 
found in Fig. 2. In summary, these data provide the first causal evidence implicating VF depletion as an important underlying cause of improved lifespan with CR.

\section{Treatment studies}

\subsection{Leptin and $\beta 3$-agonist administration}

Our group and others have demonstrated various treatment strategies for VF and/or its complications. In an initial study [83], we administered leptin by osmotic minipumps for 8 days to rats, since this fat-derived peptide had been shown to play an important role in energy homeostasis. Remarkably, we found that leptin administration led to a more dramatic decrease in VF than pair-fed controls, which were moderately food restricted, but body weight and total FM were not different. Furthermore, leptin-treated rats demonstrated the greatest enhancement in hepatic insulin action. Likewise, because the effects of leptin function primarily through the $\beta 3$-adrenoreceptor, we performed an analogous experiment designed to decrease VF to a similar extent by $\beta 3$-adrenoreceptor agonist or CR [84]. Compared to controls, hepatic insulin sensitivity was increased similarly ( $\sim 3$ fold $)$ in CR and $\beta 3$-treated animals, further demonstrating that a pharmacologic reduction in VF can improve insulin action.

\subsection{1ß-hydroxysteroid dehydrogenase inhibitors}

As previously mentioned, the enzyme $11 \beta$ HSD- 1 converts inactive cortisone into active cortisol in cells and excess glucocorticoids promote VF deposition. When this enzyme was overexpressed in adipose tissue in mice, animals developed visceral obesity and diabetes [40]. Therefore, it seemed intuitive to Hermanowski-Vosatka and colleagues that pharmacologic inhibition of $11 \beta$ HSD-1 might serve as a therapeutic target for the metabolic syndrome. When a selective and potent $11 \beta$ HSD-1 inhibitor was given to DIO mice, they observed a reduction in body mass, retroperitoneal fat pad weight, as well as serum insulin, glucose and lipids [85]. Similarly, this inhibitor resulted in improved glucose tolerance in a mouse model of T2DM and attenuated vascular plaque formation in ApoE-/- mice [85].

\subsection{Prevention of systemic inflammation}

Mounting evidence supports a role for adipose tissue-derived pro-inflammatory cytokines in the pathogenesis of diabetes and atherosclerotic diseases. Therefore, Ohmon et al. [41] administered pioglitazone, which has been shown to reduce MCP-1 levels and fat inflammation, to ApoE-I- mice that received a VF transplant or sham-operated controls. Pioglitazone treatment lowered MCP-1 levels and macrophage content in the VF transplant and reduced atherosclerosis development in VF-transplant mice, but not in sham-operated mice. Likewise, in obese mice, short-term treatment with a pharmacological antagonist of chemokine (C-C motif) receptor 2 (CCR2) lowered macrophage content in adipose tissue and systemic inflammation, resulting in improved insulin action [86]. Therefore, drugs which can interfere with the infiltration of macrophages into fat, and specifically VF, may provide an effective strategy for the prevention of cardiovascular complications and metabolic syndrome due to abdominal obesity.

\section{Perspectives}

Numerous epidemiologic studies have implicated abdominal obesity as a major risk factor for insulin resistance, T2DM, CVD, stroke, metabolic syndrome and death. Utilizing novel models of visceral obesity, several studies have demonstrated that the relationship between VF and aging is causal while the accrual of SC fat does not appear to play an important role in the etiology of disease risk. Treatment strategies including pharmacologic agents (leptin, s3agonists) can improve glucose tolerance by effectively reducing VF. Compelling evidence also supports a role for inhibitors of macrophage infiltration into fat (thiazolidinediones, CCR2 
antagonists), and hence systemic inflammation, for the treatment of insulin resistance and vascular disease. Therefore, two lines of investigation worth pursuing include (1) understanding the secretory biology of VF to identify the important mediators of the metabolic syndrome, and (2) the development of drugs designed to modulate body fat distribution. In summary, these studies highlight the consistent relationship of VF with disease and mortality risk in humans, evidence for causation in animals, the distinct metabolic capacity of VF, the importance of accounting for body fat distribution in disease risk and VF depletion as a potential treatment strategy to prevent or delay age-related diseases.

\section{Acknowledgments}

This work was supported by grants from the National Institutes of Health (AG21654 and AG18381 to NB) and by the Corelaboratories of the Albert Einstein Diabetes Research and Training Center (DK20541). DMH is supported by a postdoctoral T32 Training Grant (T32AG23475).

\section{References}

1. Monzillo LU, Hamdy O, Horton ES, Ledbury S, Mullooly C, Jarema C, Porter S, Ovalle K, Moussa A, Mantzoros CS. Effect of lifestyle modification on adipokine levels in obese subjects with insulin resistance. Obes Res 2003;11:1048-54. [PubMed: 12972674]

2. Ramas J, Courbon A, Roche F, Bethoux F, Calmels P. Effect of training programs and exercise in adult stroke patients: literature review. Ann Readapt Med Phys 2007;50:438-44. [PubMed: 17482707]

3. Gaesser GA. Exercise for prevention and treatment of cardiovascular disease, type 2 diabetes, and metabolic syndrome. Curr Diab Rep 2007;7:14-9. [PubMed: 17254513]

4. McAuley PA, Myers JN, Abella JP, Tan SY, Froelicher VF. Exercise capacity and body mass as predictors of mortality among male veterans with type 2 diabetes. Diabetes Care 2007;30:1539-43. [PubMed: 17351282]

5. Park YW, Zhu S, Palaniappan L, Heshka S, Carnethon MR, Heymsfield SB. The metabolic syndrome: prevalence and associated risk factor findings in the US population from the Third National Health and Nutrition Examination Survey, 1988-1994. Arch Intern Med 2003;163:427-36. [PubMed: 12588201]

6. Calle EE, Thun MJ, Petrelli JM, Rodriguez C, Heath CW Jr. Body-mass index and mortality in a prospective cohort of U.S. adults. N Engl J Med 1999;341:1097-105. [PubMed: 10511607]

7. Calle EE, Rodriguez C, Walker-Thurmond K, Thun MJ. Overweight, obesity, and mortality from cancer in a prospectively studied cohort of U.S. adults. N Engl J Med 2003;348:1625-38. [PubMed: 12711737]

8. Freedland SJ, Platz EA. Obesity and Prostate Cancer: Making Sense out of Apparently Conflicting Data Epidemiol Rev. 2007

9. Abrahamson PE, Gammon MD, Lund MJ, Flagg EW, Porter PL, Stevens J, Swanson CA, Brinton LA, Eley JW, Coates RJ. General and abdominal obesity and survival among young women with breast cancer. Cancer Epidemiol Biomarkers Prev 2006;15:1871-7. [PubMed: 17035393]

10. Samanic C, Chow WH, Gridley G, Jarvholm B, Fraumeni JF Jr. Relation of body mass index to cancer risk in 362,552. Swedish men Cancer Causes Control 2006;17:901-9.

11. Dignam JJ, Polite BN, Yothers G, Raich P, Colangelo L, O’Connell MJ, Wolmark N. Body mass index and outcomes in patients who receive adjuvant chemotherapy for colon cancer. J Natl Cancer Inst 2006;98:1647-54. [PubMed: 17105987]

12. Pavelka JC, Brown RS, Karlan BY, Cass I, Leuchter RS, Lagasse LD, Li AJ. Effect of obesity on survival in epithelial ovarian cancer. Cancer 2006;107:1520-4. [PubMed: 16941453]

13. Chia VM, Newcomb PA, Trentham-Dietz A, Hampton JM. Obesity, diabetes, and other factors in relation to survival after endometrial cancer diagnosis Int J Gynecol. Cancer 2007;17:441-6.

14. Carr DB, Utzschneider KM, Hull RL, Kodama K, Retzlaff BM, Brunzell JD, Shofer JB, Fish BE, Knopp RH, Kahn SE. Intra-abdominal fat is a major determinant of the National Cholesterol Education Program Adult Treatment Panel III criteria for the metabolic syndrome. Diabetes 2004;53:2087-94. [PubMed: 15277390] 
15. Bjorntorp P. "Portal" adipose tissue as a generator of risk factors for cardiovascular disease and diabetes. Arteriosclerosis 1990;10:493-6. [PubMed: 2196039]

16. Trayhurn P, Wood IS. Signalling role of adipose tissue: adipokines and inflammation in obesity. Biochem Soc Trans 2005;33:1078-81. [PubMed: 16246049]

17. Selwyn AP. Weight reduction and cardiovascular and metabolic disease prevention: clinical trial update. Am J Cardiol 2007;100:33P-37P.

18. Matsuzawa Y, Shimomura I, Nakamura T, Keno Y, Tokunaga K. Pathophysiology and pathogenesis of visceral fat obesity. Ann N Y Acad Sci 1995;748:399-406. [PubMed: 7695182]

19. Koh-Banerjee P, Wang Y, Hu FB, Spiegelman D, Willett WC, Rimm EB. Changes in body weight and body fat distribution as risk factors for clinical diabetes in US men. Am J Epidemiol 2004;159:1150-9. [PubMed: 15191932]

20. Pascot A, Lemieux S, Lemieux I, Prud'homme D, Tremblay A, Bouchard C, Nadeau A, Couillard C, Tchernof A, Bergeron J, Despres JP. Age-related increase in visceral adipose tissue and body fat and the metabolic risk profile of premenopausal women. Diabetes Care 1999;22:1471-8. [PubMed: 10480511]

21. Walker SP, Rimm EB, Ascherio A, Kawachi I, Stampfer MJ, Willett WC. Body size and fat distribution as predictors of stroke among US men. Am J Epidemiol 1996;144:1143-50. [PubMed: 8956626]

22. Nicklas BJ, Cesari M, Penninx BW, Kritchevsky SB, Ding J, Newman A, Kitzman DW, Kanaya AM, Pahor M, Harris TB. Abdominal obesity is an independent risk factor for chronic heart failure in older people. J Am Geriatr Soc 2006;54:413-20. [PubMed: 16551307]

23. Whitmer RA, Gustafson DR, Barrett-Connor E, Haan MN, Gunderson EP, Yaffe K. Central obesity and increased risk of dementia more than three decades later. Neurology 2008;71:1057-64. [PubMed: 18367704]

24. Razay G, Vreugdenhil A, Wilcock G. Obesity, abdominal obesity and Alzheimer disease. Dement Geriatr Cogn Disord 2006;22:173-6. [PubMed: 16847377]

25. Guallar-Castillon P, Sagardui-Villamor J, Banegas JR, Graciani A, Fornes NS, Lopez Garcia E, Rodriguez-Artalejo F. Waist circumference as a predictor of disability among older adults. Obesity (Silver Spring) 2007;15:233-44. [PubMed: 17228052]

26. Robles-Cervantes JA, Yanez-Diaz S, Cardenas-Camarena L. Modification of insulin, glucose and cholesterol levels in nonobese women undergoing liposuction: is liposuction metabolically safe? Ann Plast Surg 2004;52:64-7. [PubMed: 14676702]

27. Giese SY, Bulan EJ, Commons GW, Spear SL, Yanovski JA. Improvements in cardiovascular risk profile with large-volume liposuction: a pilot study. Plast Reconstr Surg 2001;108:510-9. [PubMed: 11496197]discussion 520-1

28. Gonzalez-Ortiz M, Robles-Cervantes JA, Cardenas-Camarena L, Bustos-Saldana R, MartinezAbundis E. The effects of surgically removing subcutaneous fat on the metabolic profile and insulin sensitivity in obese women after large-volume liposuction treatment. Horm Metab Res 2002;34:4469. [PubMed: 12198600]

29. Samdal F, Birkeland KI, Ose L, Amland PF. Effect of large-volume liposuction on sex hormones and glucose- and lipid metabolism in females. Aesthetic Plast Surg 1995;19:131-5. [PubMed: 7598023]

30. Enzi G, Cagnoni G, Baritussio A, De Biasi F, Favaretto L, Inelmen EM, Crepaldi G. Effects of fat mass reduction by dieting and by lipectomy on carbohydrate metabolism in obese patients. Acta Diabetol Lat 1979;16:147-56. [PubMed: 484164]

31. Lambert EV, Hudson DA, Bloch CE, Koeslag JH. Metabolic response to localized surgical fat removal in nonobese women. Aesthetic Plast Surg 1991;15:105-10. [PubMed: 2035358]

32. Ybarra J, Blanco-Vaca F, Fernandez S, Castellvi A, Bonet R, Palomer X, Ordonez-Llanos J, Trius A, Vila-Rovira R, Perez A. The effects of liposuction removal of subcutaneous abdominal fat on lipid metabolism are independent of insulin sensitivity in normal-overweight individuals. Obes Surg 2008;18:408-14. [PubMed: 18264836]

33. Klein S, Fontana L, Young VL, Coggan AR, Kilo C, Patterson BW, Mohammed BS. Absence of an effect of liposuction on insulin action and risk factors for coronary heart disease. N Engl J Med 2004;350:2549-57. [PubMed: 15201411] 
34. Buettner R, Scholmerich J, Bollheimer LC. High-fat diets: modeling the metabolic disorders of human obesity in rodents. Obesity (Silver Spring) 2007;15:798-808. [PubMed: 17426312]

35. Kim SP, Catalano KJ, Hsu IR, Chiu JD, Richey JM, Bergman RN. Nocturnal free fatty acids are uniquely elevated in the longitudinal development of diet-induced insulin resistance and hyperinsulinemia. Am J Physiol Endocrinol Metab 2007;292:E1590-8. [PubMed: 17264230]

36. Powell CS, Blaylock ML, Wang R, Hunter HL, Johanning GL, Nagy TR. Effects of energy expenditure and Ucp1 on photoperiod-induced weight gain in collard lemmings. Obes Res 2002;10:541-50. [PubMed: 12075603]

37. Davey RA, MacLean HE. Current and future approaches using genetically modified mice in endocrine research. Am J Physiol Endocrinol Metab 2006;291:E429-38. [PubMed: 16684850]

38. Friedman JM, Halaas JL. Leptin and the regulation of body weight in mammals. Nature 1998;395:763-70. [PubMed: 9796811]

39. Bjorntorp P. Hormonal control of regional fat distribution. Hum Reprod 1997;12(Suppl 1):21-5. [PubMed: 9403318]

40. Masuzaki H, Paterson J, Shinyama H, Morton NM, Mullins JJ, Seckl JR, Flier JS. A transgenic model of visceral obesity and the metabolic syndrome. Science 2001;294:2166-70. [PubMed: 11739957]

41. Ohman MK, Shen Y, Obimba CI, Wright AP, Warnock M, Lawrence DA, Eitzman DT. Visceral adipose tissue inflammation accelerates atherosclerosis in apolipoprotein E-deficient mice. Circulation 2008;117:798-805. [PubMed: 18212290]

42. Barzilai N, She L, Liu BQ, Vuguin P, Cohen P, Wang J, Rossetti L. Surgical removal of visceral fat reverses hepatic insulin resistance. Diabetes 1999;48:94-8. [PubMed: 9892227]

43. Einstein FH, Fishman S, Muzumdar RH, Yang XM, Atzmon G, Barzilai N. Accretion of Visceral Fat and Hepatic Insulin Resistance in Pregnant Rats. Am J Physiol Endocrinol Metab. 2007

44. Borst SE, Conover CF, Bagby GJ. Association of resistin with visceral fat and muscle insulin resistance. Cytokine 2005;32:39-44. [PubMed: 16154759]

45. Gabriely I, Ma XH, Yang XM, Atzmon G, Rajala MW, Berg AH, Scherer P, Rossetti L, Barzilai N. Removal of visceral fat prevents insulin resistance and glucose intolerance of aging: an adipokinemediated process? Diabetes 2002;51:2951-8. [PubMed: 12351432]

46. Pitombo C, Araujo EP, De Souza CT, Pareja JC, Geloneze B, Velloso LA. Amelioration of dietinduced diabetes mellitus by removal of visceral fat. J Endocrinol 2006;191:699-706. [PubMed: 17170226]

47. Kim JY, van de Wall E, Laplante M, Azzara A, Trujillo ME, Hofmann SM, Schraw T, Durand JL, Li H, Li G, Jelicks LA, Mehler MF, Hui DY, Deshaies Y, Shulman GI, Schwartz GJ, Scherer PE. Obesity-associated improvements in metabolic profile through expansion of adipose tissue. J Clin Invest 2007;117:2621-37. [PubMed: 17717599]

48. Rissanen A, Heliovaara M, Knekt P, Aromaa A, Reunanen A, Maatela J. Weight and mortality in Finnish men. J Clin Epidemiol 1989;42:781-9. [PubMed: 2760670]

49. Lindsted K, Tonstad S, Kuzma JW. Body mass index and patterns of mortality among Seventh-day Adventist men. Int J Obes 1991;15:397-406. [PubMed: 1885263]

50. Bender R, Jockel KH, Trautner C, Spraul M, Berger M. Effect of age on excess mortality in obesity. Jama 1999;281:1498-504. [PubMed: 10227319]

51. Allison DB, Fontaine KR, Manson JE, Stevens J, VanItallie TB. Annual deaths attributable to obesity in the United States. Jama 1999;282:1530-8. [PubMed: 10546692]

52. Fontaine KR, Redden DT, Wang C, Westfall AO, Allison DB. Years of life lost due to obesity. Jama 2003;289:187-93. [PubMed: 12517229]

53. Valdes AM, Andrew T, Gardner JP, Kimura M, Oelsner E, Cherkas LF, Aviv A, Spector TD. Obesity, cigarette smoking, and telomere length in women. Lancet 2005;366:662-4. [PubMed: 16112303]

54. Stevens J, Keil JE, Rust PF, Tyroler HA, Davis CE, Gazes PC. Body mass index and body girths as predictors of mortality in black and white women. Arch Intern Med 1992;152:1257-62. [PubMed: 1599355]

55. Folsom AR, Kaye SA, Sellers TA, Hong CP, Cerhan JR, Potter JD, Prineas RJ. Body fat distribution and 5-year risk of death in older women. Jama 1993;269:483-7. [PubMed: 8419667] 
56. Baik I, Ascherio A, Rimm EB, Giovannucci E, Spiegelman D, Stampfer MJ, Willett WC. Adiposity and mortality in men. Am J Epidemiol 2000;152:264-71. [PubMed: 10933273]

57. Wannamethee SG, Shaper AG, Lennon L, Whincup PH. Decreased muscle mass and increased central adiposity are independently related to mortality in older men. Am J Clin Nutr 2007;86:1339-46. [PubMed: 17991644]

58. Pischon T, Boeing H, Hoffmann K, Bergmann M, Schulze MB, Overvad K, van der Schouw YT, Spencer E, Moons KG, Tjonneland A, Halkjaer J, Jensen MK, Stegger J, Clavel-Chapelon F, Boutron-Ruault MC, Chajes V, Linseisen J, Kaaks R, Trichopoulou A, Trichopoulos D, Bamia C, Sieri S, Palli D, Tumino R, Vineis P, Panico S, Peeters PH, May AM, Bueno-de-Mesquita HB, van Duijnhoven FJ, Hallmans G, Weinehall L, Manjer J, Hedblad B, Lund E, Agudo A, Arriola L, Barricarte A, Navarro C, Martinez C, Quiros JR, Key T, Bingham S, Khaw KT, Boffetta P, Jenab M, Ferrari P, Riboli E. General and abdominal adiposity and risk of death in Europe. N Engl J Med 2008;359:2105-20. [PubMed: 19005195]

59. Tannenbaum A. The genesis and growth of tumors. II. Effects of caloric restriction per se. Cancer Res 1942;2:460-464.

60. Tannenbaum A. The dependence of the genesis of induced skin tumors on the caloric intake during different stages of carcinogenesis. Cancer Res 1944;4:673-679.

61. Nutrition classics. The American Journal of Cancer, Volume XXXVIII, March, 1940: The initiation and growth of tumors. Introduction. I. Effects of underfeeding. By Albert Tannenbaum. Nutr Rev 1987;45:20-2. [PubMed: 3547194]

62. Weindruch R, Walford R. The Retardation of Aging and Disease by Dietary Restriction. 1988

63. Masoro EJ. Overview of caloric restriction and ageing. Mech Ageing Dev 2005;126:913-22. [PubMed: 15885745]

64. Kealy RD, Lawler DF, Ballam JM, Mantz SL, Biery DN, Greeley EH, Lust G, Segre M, Smith GK, Stowe HD. Effects of diet restriction on life span and age-related changes in dogs. J Am Vet Med Assoc 2002;220:1315-20. [PubMed: 11991408]

65. Roth GS, Ingram DK, Lane MA. Caloric restriction in primates and relevance to humans. Ann N Y Acad Sci 2001;928:305-15. [PubMed: 11795522]

66. Pinney DO, Stephens DF, Pope LS. Lifetime effects of winter supplemental feed level and age at first parturition on range beef cows. J Anim Sci 1972;34:1067-74. [PubMed: 5027302]

67. Pugh TD, Klopp RG, Weindruch R. Controlling caloric consumption: protocols for rodents and rhesus monkeys. Neurobiol Aging 1999;20:157-65. [PubMed: 10537025]

68. Bertrand HA, Lynd FT, Masoro EJ, Yu BP. Changes in adipose mass and cellularity through the adult life of rats fed ad libitum or a life-prolonging restricted diet. J Gerontol 1980;35:827-35. [PubMed: 7440923]

69. Masoro EJ. Commentary on "Revisiting the role of fat mass in the life extension induced by caloric restriction". J Gerontol A Biol Sci Med Sci 1999;54A:B97.

70. Speakman JR. Body size, energy metabolism and lifespan. J Exp Biol 2005;208:1717-30. [PubMed: 15855403]

71. Bluher M, Kahn BB, Kahn CR. Extended longevity in mice lacking the insulin receptor in adipose tissue. Science 2003;299:572-4. [PubMed: 12543978]

72. Barzilai N, Gupta G. Revisiting the role of fat mass in the life extension induced by caloric restriction. J Gerontol A Biol Sci Med Sci 1999;54:B89-96. [PubMed: 10191831]discussion B97-8

73. Harrison DE, Archer JR, Astle CM. Effects of food restriction on aging: separation of food intake and adiposity. Proc Natl Acad Sci U S A 1984;81:1835-8. [PubMed: 6608731]

74. Berg BN, Simms HS. Nutrition and longevity in the rat. II. Longevity and onset of disease with different levels of food intake. J Nutr 1960;71:255-63. [PubMed: 13855553]

75. Zhang Y, Proenca R, Maffei M, Barone M, Leopold L, Friedman JM. Positional cloning of the mouse obese gene and its human homologue. Nature 1994;372:425-32. [PubMed: 7984236]

76. Fontana L, Meyer TE, Klein S, Holloszy JO. Long-Term Low-Calorie Low-Protein Vegan Diet and Endurance Exercise Are Associated with Low Cardiometabolic Risk Rejuvenation Res. 2007

77. Rose DP, Komninou D, Stephenson GD. Obesity, adipocytokines, and insulin resistance in breast cancer. Obes Rev 2004;5:153-65. [PubMed: 15245384] 
78. Frankenberry KA, Somasundar P, McFadden DW, Vona-Davis LC. Leptin induces cell migration and the expression of growth factors in human prostate cancer cells. Am J Surg 2004;188:560-5. [PubMed: 15546570]

79. Barzilai N, Banerjee S, Hawkins M, Chen W, Rossetti L. Caloric restriction reverses hepatic insulin resistance in aging rats by decreasing visceral fat. J Clin Invest 1998;101:1353-61. [PubMed: 9525977]

80 . Weindruch R. The retardation of aging by caloric restriction: studies in rodents and primates. Toxicol Pathol 1996;24:742-5. [PubMed: 8994305]

81. Wang C, Weindruch R, Fernandez JR, Coffey CS, Patel P, Allison DB. Caloric restriction and body weight independently affect longevity in Wistar rats. Int J Obes Relat Metab Disord 2004;28:35762. [PubMed: 14724654]

82. Muzumdar R, Allison DB, Huffman DM, Ma X, Atzmon G, Einstein FH, Fishman S, Poduval AD, McVei T, Keith SW, Barzilai N. Visceral adipose tissue modulates mammalian longevity. Aging Cell 2008;7:438-40. [PubMed: 18363902]

83. Barzilai N, Wang J, Massilon D, Vuguin P, Hawkins M, Rossetti L. Leptin selectively decreases visceral adiposity and enhances insulin action. J Clin Invest 1997;100:3105-10. [PubMed: 9399957]

84. Barzilai N, Gabriely I. The role of fat depletion in the biological benefits of caloric restriction. J Nutr 2001;131:903S-906S. [PubMed: 11238783]

85. Hermanowski-Vosatka A, Balkovec JM, Cheng K, Chen HY, Hernandez M, Koo GC, Le Grand CB, Li Z, Metzger JM, Mundt SS, Noonan H, Nunes CN, Olson SH, Pikounis B, Ren N, Robertson N, Schaeffer JM, Shah K, Springer MS, Strack AM, Strowski M, Wu K, Wu T, Xiao J, Zhang BB, Wright SD, Thieringer R. 11beta-HSD1 inhibition ameliorates metabolic syndrome and prevents progression of atherosclerosis in mice. J Exp Med 2005;202:517-27. [PubMed: 16103409]

86. Weisberg SP, Hunter D, Huber R, Lemieux J, Slaymaker S, Vaddi K, Charo I, Leibel RL, Ferrante AW Jr. CCR2 modulates inflammatory and metabolic effects of high-fat feeding. J Clin Invest 2006;116:115-24. [PubMed: 16341265] 


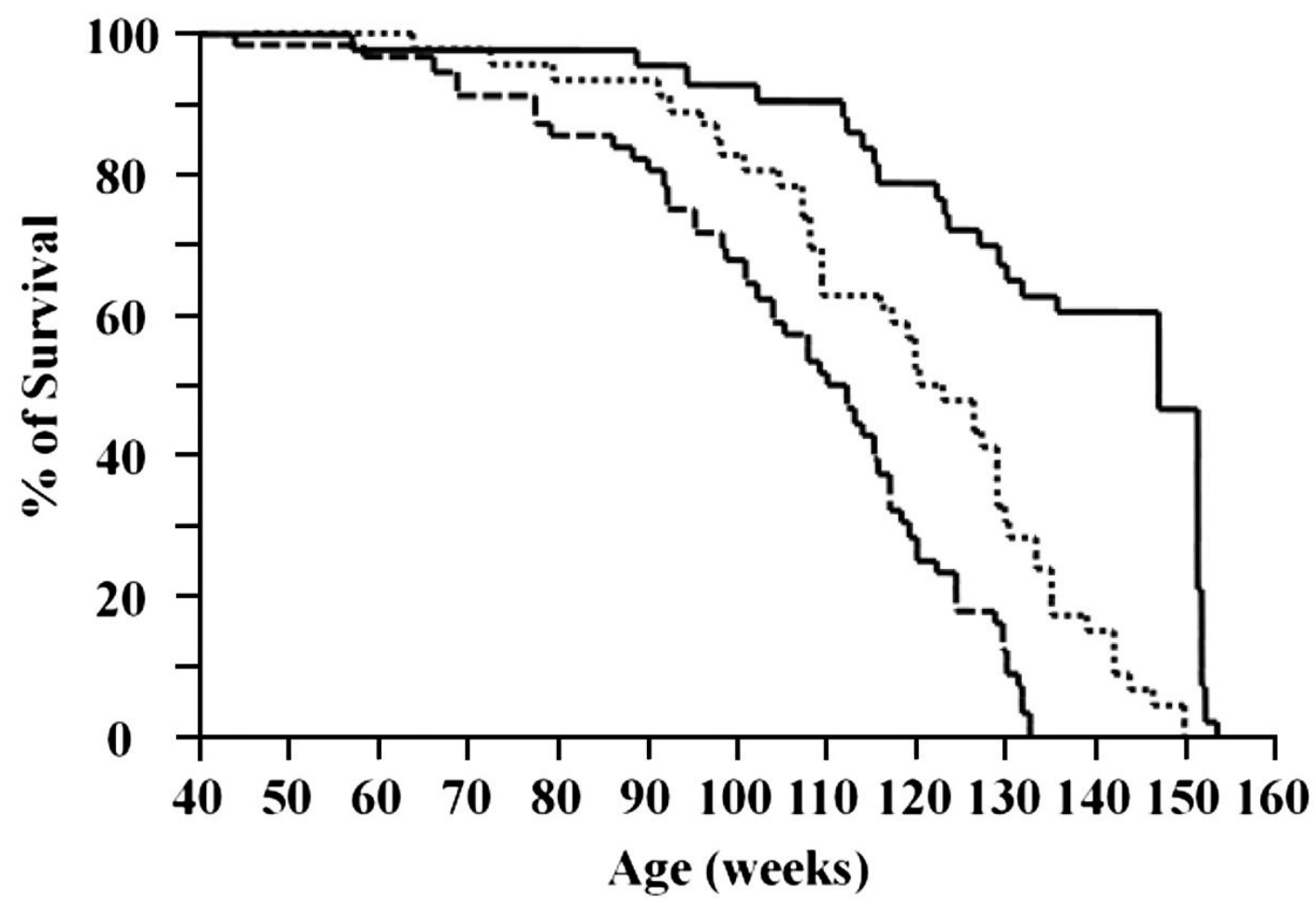

Figure 1.

Survival curve of the three groups of rats (AL-fed, dashed line; VF-removed, dotted line; and $\mathrm{CR}$, solid line). CR rats had the greatest mean and maximum lifespan but VF removal only was sufficient to extend lifespan as compared to AL controls and accounted for nearly $20 \%$ of the CR effect on lifespan. Figure is from Muzumdar et al. [82] and is presented with permission from Aging Cell. 


\section{Visceral fat accumulation}
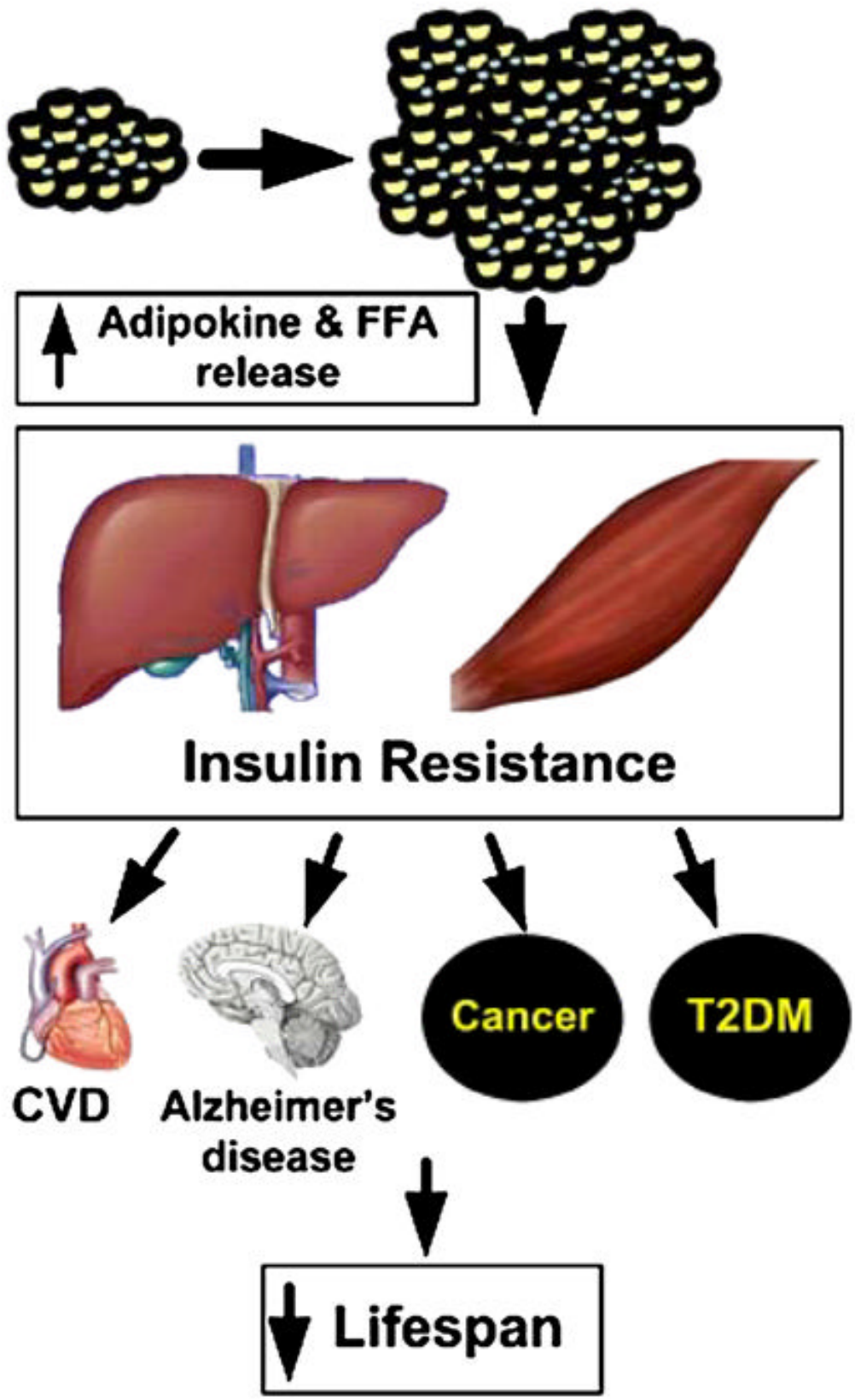

Figure 2.

The proposed link among VF, age-related diseases and lifespan. The accumulation of VF, which is a hallmark of aging, is hypothesized to pose a greater risk for the development of insulin resistance and other features of the metabolic syndrome than other fat depots due to its anatomical location, high lipolytic rate and secretion of inflammatory adipokines. Some specific perturbations to tissues by increased VF include hepatic insulin resistance, impaired glucose uptake by skeletal muscle and increased basal lipolytic rate and FFA release by adipose tissue. The long-term consequence of VF-induced metabolic decline includes enhanced risk for several age-related diseases such as CVD, T2DM, Alzheimer's disease and certain cancers. Therefore, VF accretion would be expected to increase mortality risk and reduce lifespan. 


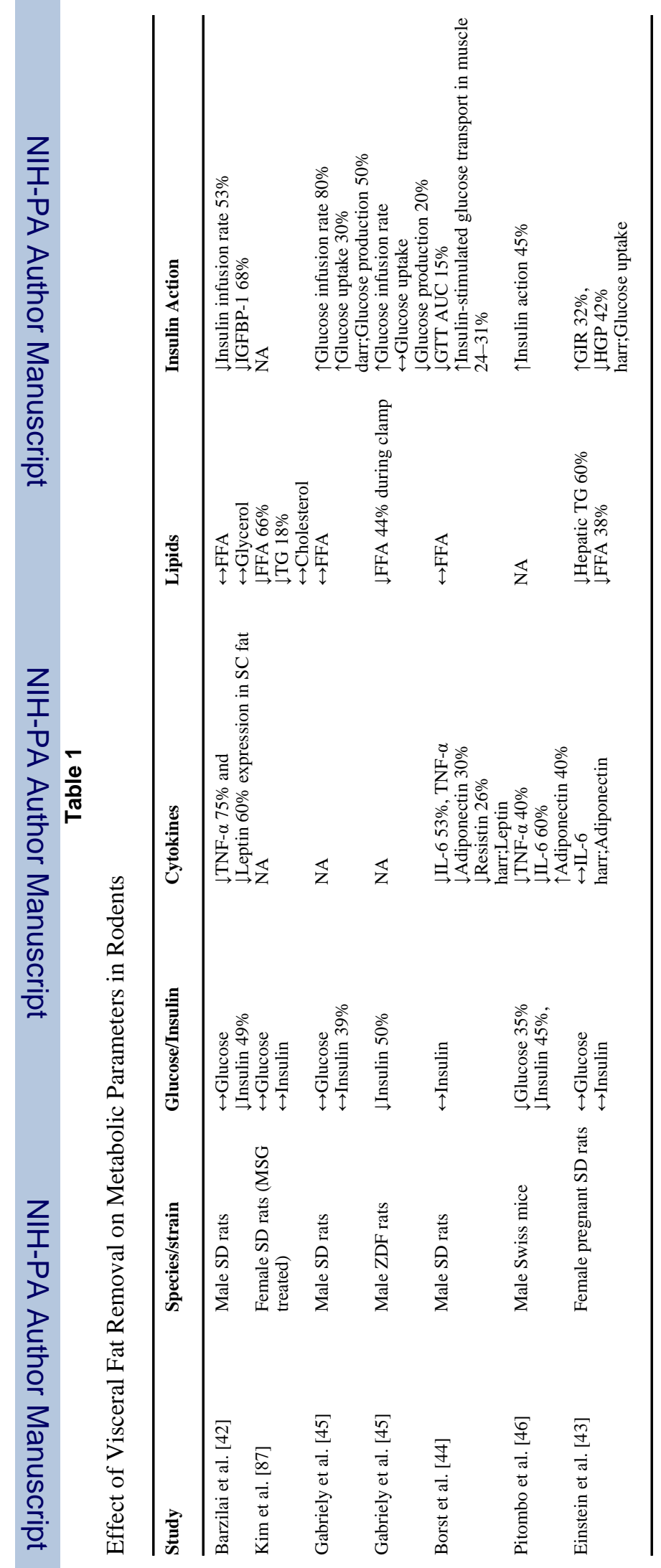

